\title{
Pengaruh Subtitusi Tepung Daun Kumis Kucing (Orthosiphon Stamineus B.) Terhadap Mutu Gizi Sus Kering Sebagai Makanan Selingan Pasien Kemoterapi
}

\author{
Nur Amaliah Ahmad ${ }^{1}$, Laksmi Karunia Tanuwijaya ${ }^{1}$, Rahma Micho Widyanto ${ }^{1}$ \\ ${ }^{1}$ Program Studi Ilmu Gizi, Fakultas Kedokteran, Universitas Brawijaya (UB), \\ Jl. Veteran, Malang, Jawa Timur 65145
}

Penulis untuk Korespondensi/E-mail: amaliahahmad@student.ub.ac.id

\begin{abstract}
Abstrak -Kemoterapi merupakan terapi pengobatan kanker dengan menggunakan obat-obatan sitostatika untuk menghancurkan sel kanker atau menghambat perkembangan sel kanker.Efek samping dari pengobatan kemoterapi berupa anoreksia, mual dan muntah, sehingga dapat mempengaruhi asupan makan pasien dan menyebabkan pasien mengalami malnutrisi. Sus Kering merupakan makanan yang dibuat untuk pasien kemoterapi dengan ukuran kecil namun memiliki kandungan gizi yang tinggi.Penelitian ini bertujuan untuk mengetahui perbedaan kandungan zat gizi makrodan energi total pada sus kering substitusi tepung daun kumis kucing pada keempat formulasi terbaik dengan komposisi tepung terigu: tepung daun kumis kucing masing-masing (P0) 100:0 ; (P1) 90:10, (P2) 85:15, (P3) 80:20. Desain penelitian true experimental dengan menggunakan rancangan acak lengkap dengan menggunakan variabel kontrol dan tiga perlakuan. Ulangan dilakukan sebanyak 3 kali sehingga total sampel sebanyak 12. Hasil penelitian menunjukkan bahwa rata-rata kadar zat gizi dan energi total pada sus kering substitusi tepung daun kumis kucing secara berturut-turut sebagai berikut, karbohidrat 10,30 gram, protein 3,71 gram, lemak 10,18 gram dan energi 146,21 kkal per satu takaran saji atau 25 gram. Hasil analisis statistik uji beda One Way Anova dan Kruskal Wallis menunjukkan tidak ada perbedaan signifikan pada karbohidrat, protein, lemak dan energi $(\mathbf{p}>0,05)$. Dapat disimpulkan bahwa tepung daun kumis kucing tidak mempengaruhi kandungan zat gizi makro dan energi total pada sus kering substitusi tepung daun kumis kucing sebagai makanan selingan pasien kemoterapi.
\end{abstract}

Abstract - Chemotherapy is a cancer treatment therapy by using cytotoxic medicines to eliminate cancer cells or inhibit the growth of cancer cells. Side effects of chemotherapy medication are anorexia, nausea, and vomit that impact the absorption of nutrition and malnutrition to the patients. Choux paste is a food specially designed for chemotherapy patients in small size but have high nutrition. This study aims to investigate the difference of macronutrients content and total energy of chou pastry with Java Tea (Orthosiphon stamineus) based flour with four best formulation that has a composition of wheat flour: Java Tea based flour with the ratio of each (P0) 100:0 (P1) 90:10 (P2) 85:15 (P3) 80:20. This study conducted with a true experimental design that used a completely randomized design method with control variables and three treatments. Repetition is performed three times for 12 total samples. Results are shown that mean of macronutrients level and total energy of chou pastry with Java Tea based flour are as follows, carbohydrate 10,30 grams, protein 3,71 grams, fat 10,18 grams, and energy 146,21 kcal for one serving size or 25 gram. The comparative study of One Way Anova and Kruskal Wallis showed that there are no significant differences in carbohydrate, protein, fat, and energy ( $p>0.05)$. It can be concluded that Java Tea whiskers based flour does not affect macronutrient content and total energy of choux pastry with Java Tea based flour as a snack for a chemotherapy patient.

Keywords -Tepung daun kumis kucing, Kadar karbohidrat, Protein, Lemak, Energi, Sus kering, Kemoterapi 


\section{PENDAHULUAN}

$\mathrm{K}$ emoterapi merupakan terapi untuk penderita kanker dengan cara pemberian segolong obatobatan sitostatika yang bertujuan untuk menghambat pertumbuhan ataupun membunuh sel kanker dengan cara menghentikan pembelahan selnya [1]. Kanker merupakan penyakit tidak menular yang menjadi masalah kesehatan masyarakat di dunia. Pada tahun 2018, kanker menjadi penyebab kematian sekitar 9,6 juta orang (WHO, 2018). Sedangkan di Indonesia prevalensi kanker tertinggi terletak di provinsi DI. Yogyakarta sebesar 4,9\% [2] [3].

Sebagian besar pasien kemoterapi sering mengalami gangguan makan akibat efek samping terapi yang digunakan sehingga menyebabkan malnutrisi pada saat menjalani terapi. Kejadian malnutrisi tersebut bervariasi misalnya mual muntah, anoreksia, diare, perubahan rasa terhadap makanan dan beberapa efek lain. Gangguan ini bervariasi tingkatannya, mulai dari yang ringan sampai kematian, akibat dehidrasi dan kurangnya asupan makanan [4]. Penurunan nafsu makan (anoreksia) merupakan hilangnya atau berkurangnya nafsu makan yang merupakan faktor utama dalam terjadinya malnutrisi pada penderita kanker. Faktor utama terjadinya malnutrisi karena terjadinya hipermetabolisme pada pasien. Selain itu, malnutrisi juga disebabkan karena terjadinya malabsorpsi akibat adanya perubahan proses metabolisme dalam tubuh [5].

Malnutrisi pada pasien kanker dapat meningkatkan lama rawat, memperparah keadaan klinis, respon terhadap terapi kurang signifikan dan menghambat kelancaran terapi. Oleh sebab itu, perlu adanya makanan yang dapat memenuhi kebutuhan pasien kanker. Pasien tidak hanya memerlukan makanan utama, tetapi juga makanan selingan yang mengandung zat gizi yang seimbang untuk mencapai dan meningkatkan status gizi [6].

Sus kering merupakan salah satu produk choux paste atau makanan selingan karena memiliki ukuran kecil dengan tekstur yang renyah, dan gurih. Tepung terigu merupakan bahan dasar pembuatan sus kering. Bedasarkan hasil penelitian sebelumnya produk kue kering dapat di substitusi dengan tepung daun kelor mencapai $60 \%$ [7].

Daun kumis kucing (Orthosiphon stamineus B.) merupakan obat tradisional yang mengandung berbagai macam zat yaitu kalium, polifenol, flavonoid, asam oleanolik, eupatori dan zat sinensetin yang memiliki kandungan antioksidan [8]. Daun kumis kucing mengandung flavonoid yang diduga dapat menekan proses angiogenesis sehingga dapat menghambat pertumbuhan sel tumor dan kanker [9]. Menurut penelitian yang dilakukan oleh Kusumaningrum terkait uji toksisitas bubuk daun kumis kucing pada minuman seduhan untuk tikus percobaan secara In Vivo menyatakan bahwa senyawa yang ada dalam daun kumis kucing tidak bersifat radikal sehingga tidak berbahaya dan aman dikonsumsi. Selain itu kadungan tepung daun kumis kucing dalam 100 gram sebesar $62,61 \%$ karbohidrat, $17,14 \%$ protein, 5,09\% lemak 7\% kadar air, dan 7,8\% kadar abu [10].

Sebagai upaya pemenuhan kebutuhan nutrisi, serta untuk mendapatkan manfaat kandungan dari daun kumis kucing peneliti membuat alternatif makanan selingan untuk pasien kemoterapi dengan menambahkan tepung daun kumis kucing dalam produk sus kering dengan tujuan energi sus kering sangat sesuai dengan prinsip diet pasien kemoterapi yang memerlukan makanan dalam bentuk atau porsi kecil namun tinggi energi. Untuk itu peneliti ingin mengetahui pengaruh substitusi tepung daun kumis kucing (Orthosiphon stamineus B.) terhadap mutu gizi karbohidrat, protein, dan lemak pada sus kering.

\section{METODE}

Penelitian ini merupakan penelitian true eksperimental dengan menggunakan Rancangan Acak Lengkap dengan menggunakan variabel kontrol dan tiga perlakuan. Ulangan dilakukan sebanyak 3 kali sehingga total sampel sebanyak 12 [11]. Pembuatan sus kering substitusi daun kumis kucing dilakukan di Laboratorium Penyelenggaraan Makanan, Fakultas Kedokteran, Universitas Brawijaya, Malang. Dan untuk pengujian proksimat dilakukan di Laboratorium Pengujian Mutu dan Keamanan Pangan, Fakultas Teknologi Pertanian, Universitas Brawijaya, Malang.

\section{Bahan}

Tepung daun kumis kucingyang merupakan bahan baku utama sus kering yang terbuat dari daun kumis kucing usia $3-6$ bulan kemudian dikeringkan dan digiling hingga menjadi tepung. Tepung daun kumis kucig diperoleh dari Materia 
Medika yang bertempat di Kota Batu, Jawa Timur. Bahan-bahan lainnya yang digunakan pada pembuatan sus kering seperti tepung terigu, margarin, soda kue, telur, dan garam diperoleh dari Toko Kue Prima Rasa, Malang, Jawa Timur.

\section{Prosedur Penelitian}

Penentuan formulasi sus kering berdasarkan resep yang telah diterapkan pada produk sus kering dengan substitusi tepung daun kumis kucing dengan batas maksimal 25 gram. Hal ini dikarenakan jika penambahan tepung daun kumis kucing lebih dari 25 gram maka rasa yang dihasilkan pahit dan warna yang dihasilkan kurang menarik. Perbandingan bahan yang digunakan sebagai berikut :

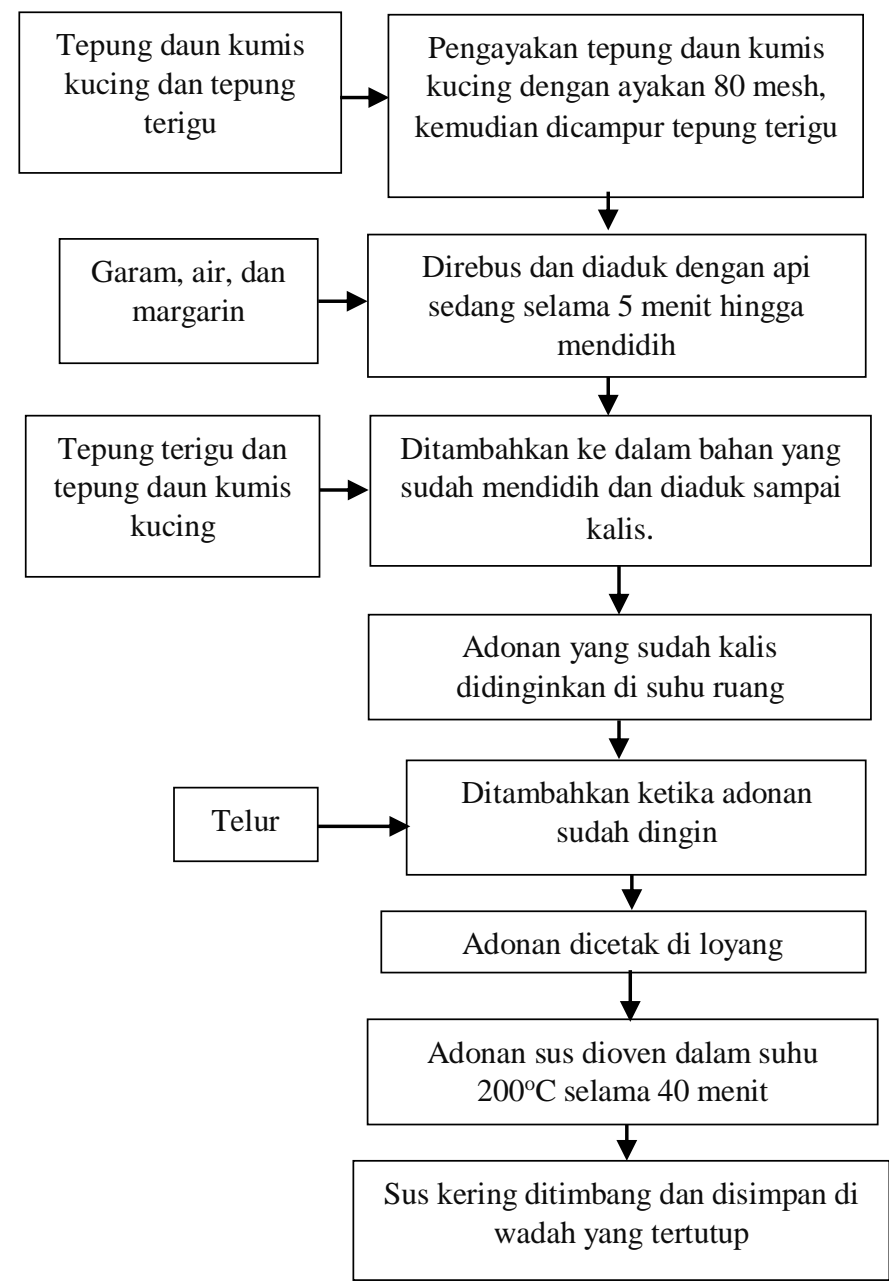

Gambar 1. Bagan Alur Prosedur Penelitian
Tabel 1. Komposisi bahan per $100 \mathrm{~g}$ sus kering

\begin{tabular}{lllll}
\hline \multirow{2}{*}{ Jenis Bahan } & \multicolumn{4}{c}{ Berat (g) } \\
\cline { 2 - 5 } & \multicolumn{1}{c}{ P0 } & P1 & \multicolumn{1}{c}{ P2 } & P3 \\
\hline Tepung terigu & 125 & 112,5 & 106,25 & 100 \\
\hline $\begin{array}{l}\text { Tepung daun } \\
\text { kumis kucing }\end{array}$ & - & 12,5 & 18,75 & 25 \\
\hline Margarin & 100 & 100 & 100 & 100 \\
\hline Telur & 180 & 180 & 180 & 180 \\
\hline Air & 250 & 250 & 250 & 250 \\
\hline Garam & 1 & 1 & 1 & 1 \\
\hline Baking powder & 1 & 1 & 1 & 1 \\
\hline
\end{tabular}

\section{Analisis Data}

Data analisis zat gizi makro diperoleh dari analisis proksimat dengan analisis karbohidrat menggunakan metode by difference, kadar protein dengan metode Kjeldahl, dan kadar lemak dengan metode Soxhlet. Kemudian, dari hasil tersebut untuk mendapatkan hasil energi dihitung berdasakan jumlah karbohidrat, protein, dan lemak yang kemudian dikalikan dengan nilai kalori masing-masing makronutrien yaitu untuk karbohidrat $4 \mathrm{kkal}$, lemak $9 \mathrm{kkal}$, dan protein 4 kkal.

Analisis data karbohidrat, protein, lemak, dan kalori diuji dengan SPSS 16,0 dari 12 sampel sus kering akan dilakukan dengan menggunakan uji statistik One Way Annova jika data terdistribusi normal dan homogen dengan tingkat kepercayaan 95\%. Dan jika data tidak terdistribusi normal dan tidak homogen maka manggunakan uji Kruskal Wallis.

\section{HASIL DAN PEMBAHASAN}

\section{Analisa Bahan Baku}

Uji pendahuluan yang dilakukan oleh peneliti adalah menganalisa kadar protein dengan menggunakan metode Kjeldahl, karbohidrat menggunakan metode by difference dan lemak dengan menggunakan metode Soxhlet dengan bahan baku utama dari sus kering yaitu tepung daun kumis kucing. Tepung daun kumis kucing memiliki kadar karbohidrat $62,61 \%$, protein 17,14 , lemak $5,09 \%$. 


\section{Karakteristik Produk}

Penelitian ini memiliki empat perlakuan, yaitu P0, P1, P2, dan P3 yang masing-masing perlakuan memiliki karakteristik yang berbeda. Metode yang dilakukan untuk menentukan karakeristik dari produk yaitu dengan menggunakan pengamatan visual yang dilakukan oleh peneliti. Hasil dari pengamatan yaitu, P0 memiliki karakteristik produk yang mirip dengan sus kering komersial sementara P1, P2, dan P3 memiliki karakteristik produk yang berbeda dengan P0 dari segi rasa, aroma, dan warna karena dilakukan substitusi tepung daun kumis kucing dengan jumlah yang berbeda tiap perlakuanseperti yang tampak pada Tabel 2.

\section{Kadar Karbohidrat pada Sus Kering}

Tabel 3 menunjukkan reratakadar karbohidrat dari keempat perlakuan sus kering yang diperoleh dengan analisis by difference. Hasil uji statistik menunjukkan bahwa data tidak homogen dengan uji Kruskal Wallis menunjukkan penambahan tepung daun kumis kucing pada pembuatan sus kering tidak memberikan perbedaan yang signifikan kadar karbohidrat pada sus kering dengan substitusi tepung daun kumis kucing pada ketiga perlakuan $(p>0,05)$.

\section{Kadar Protein pada Sus Kering}

Tabel 3 menunjukkan rerata kadar protein dari keempat perlakuan sus kering yang diperoleh dengan analisis Kjeldahl. Hasil uji statistik menunjukkan bahwa data homogen dan dengan uji One Way Anova menunjukkan penambahan tepung daun kumis kucing pada pembuatan sus kering tidak memberikan perbedaan yang signifikan kadar Protein pada sus kering dengan substitusi tepung daun kumis kucing pada ketiga perlakuan $(p>0,05)$.

\section{Kadar Lemak pada Sus Kering}

Tabel 3 menunjukkan rerata kadar Lemak dari keempat perlakuan sus kering yang diperoleh dengan analisis Soxhlet. Hasil uji statistik menunjukkan bahwa data tidak homogen dan dengan uji Kruskal Wallis menunjukkan penambahan tepung daun kumis kucing pada pembuatan sus kering tidak memberikan perbedaan yang signifikan kadar lemak pada sus kering dengan substitusi tepung daun kumis kucing pada ketiga perlakuan $(\mathrm{p}>0,05)$.

\section{Energi Total pada Sus Kering}

Tabel 3 menunjukkan rerata energi total dari keempat perlakuan sus kering yang diperoleh dengan mengkalikan dengan nilai kalori masingmasing makronutrien yaitu untuk karbohidrat 4 $\mathrm{kkal}$, lemak $9 \mathrm{kkal}$, dan protein $4 \mathrm{kkal}$. Hasil uji statistik menunjukkan bahwa data tidak homogen dan dengan uji Kruskal Wallis menunjukkan penambahan tepung daun kumis kucing pada pembuatan sus kering tidak memberikan perbedaan yang signifikan energi total pada sus kering dengan substitusi tepung daun kumis kucing pada ketiga perlakuan $(\mathrm{p}>0,05)$.

Tabel 2. Karakteristik Produk

\begin{tabular}{|c|c|c|c|c|}
\hline \multirow[t]{2}{*}{ Perlakuan } & \multicolumn{4}{|c|}{ Karakteristik } \\
\hline & Warna & Aroma & Rasa & Tekstur \\
\hline P0 & $\begin{array}{c}\text { Kuning } \\
\text { keemasan }\end{array}$ & Aroma khas sus kering & Gurih & Renyah \\
\hline $\mathrm{P} 1$ & $\begin{array}{c}\text { Hijau } \\
\text { kecoklatan }\end{array}$ & $\begin{array}{l}\text { Aroma herbal khas kumis } \\
\text { kucing }\end{array}$ & Gurih & Renyah \\
\hline $\mathrm{P} 2$ & $\begin{array}{c}\text { Hijau } \\
\text { kecoklatan }\end{array}$ & $\begin{array}{c}\text { Aroma herbal khas kumis } \\
\text { kucing }\end{array}$ & $\begin{array}{c}\text { Gurih namun memiliki } \\
\text { aftertaste pahit }\end{array}$ & Renyah \\
\hline P3 & $\begin{array}{l}\text { Hijau gelap } \\
\text { kecoklatan }\end{array}$ & $\begin{array}{l}\text { Aroma herbal khas daun } \\
\text { kumis kucing }\end{array}$ & $\begin{array}{c}\text { Gurih namun memiliki } \\
\text { aftertaste pahit }\end{array}$ & Renyah \\
\hline
\end{tabular}


Tabel 3. Nilai Rerata Karbohidrat, Protein, Lemak, dan Energi Sus Kering

\begin{tabular}{ccccc}
\hline Perlakuan & $\begin{array}{c}\text { Kadar Karbohidrat } \\
(\% / 100 \mathrm{~g}) \pm \mathrm{SD}\end{array}$ & $\begin{array}{c}\text { Kadar } \\
\text { Protein }(\% / 100 \mathrm{~g}) \pm \\
\mathrm{SD}\end{array}$ & $\begin{array}{c}\text { Kadar Lemak } \\
(\% 100 \mathrm{~g}) \pm \mathrm{SD}\end{array}$ & $\begin{array}{c}\text { Energi Total } \\
(\mathrm{kkal}) \pm \mathrm{SD}\end{array}$ \\
\hline P0 & $41,22 \pm 4,73$ & $13,38 \pm 1,06$ & $37,59 \pm 0,30$ & $568,71 \pm 1,25$ \\
P1 & $39,71 \pm 0,98$ & $14,87 \pm 0,85$ & $40,72 \pm 0,20$ & $584,84 \pm 1,33$ \\
P2 & $37,78 \pm 6,29$ & $12,73 \pm 1,53$ & $37,71 \pm 4,80$ & $541,46 \pm 6,69$ \\
P3 & $39,66 \pm 2,13$ & $13,46 \pm 0,55$ & $39,95 \pm 1,45$ & $569,09 \pm 1,97$ \\
P Value & 0,999 & 0,171 & 0,204 & 0,218 \\
\hline
\end{tabular}

Tabel 4. Nilai Rerata Kadar Abu dan Kadar Air Sus Kering

\begin{tabular}{ccc}
\hline Perlakuan & $\begin{array}{c}\text { Kadar Air }(\% / 100 \mathrm{~g}) \pm \\
\text { SD }\end{array}$ & $\begin{array}{c}\text { Kadar } \\
\mathrm{Abu}(\% / 100 \mathrm{~g}) \pm \mathrm{SD}\end{array}$ \\
\hline P0 & $5,41 \pm 3,63$ & $2,39 \pm 0,13$ \\
P1 & $1,85 \pm 0,13$ & $2,84 \pm 0,10$ \\
P2 & $11,21 \pm 9,37$ & $2,85 \pm 0,47$ \\
P3 & $3,63 \pm 3,85$ & $3,28 \pm 0,15$ \\
P Value & 0,838 & 0,056 \\
\hline
\end{tabular}

\section{Karakteristik Sus Kering}

Pada penelitian sus kering subtitusi tepung daun kumis kucing P0 memiliki warna kuning keemasan sedangkan sus kering dengan subtitusi tepung daun kumis kucing P1, P2, dan P3 memiliki warna hijau kecoklatan. Warna hijau kecoklatan tersebut dipengaruhi oleh tepung daun kumis kucing, semakin besar subtitusi tepung kumis kucing semakin memberi warna yang kecoklatan. Umumnya bahan makanan memiliki warna karena adanya pigmen pada tanaman yaitu klorofil. Sehingga memberikan warna kehijauan pada daun kumis kucing. Sedangkan warna kecoklatan akibat dari proses pengeringan tepung daun kumis kucing pada oven sehingga warna daun kumis kucing menjadi hijau kecoklatan [12].

Aroma yang dihasilkan tidak memiliki perbedaan yang signifikan pada P1 memiliki aroma khas kumis kucing tetapi tidak pekat jika dibandingkan P2 dan P3. Aroma khas daun kumis kucing dihasilkan dari minyak atsiri yang merupakan minyak dari tanaman yang komponennya mudah menguap karena titik uapnya rendah dan bersifat khas [13]. Selain itu, tidak ada perbedaan signifikan terkait tekstur yang dihasilkan yaitu kering renyah. Kerenyahan produk sus kering dipengaruhi oleh kandungan pati pada telur dan tepung terigu. Kandungan ovalbumin pada telur sebagai foaming agent yang membantu menangkap udara yang apabila dipanaskan dengan suhu yang tinggi struktur adonan akan terbentuk dan menyebabkan rongga sehingga produk yang dihasilkan menjadi renyah [14].

Rasa dari sus kering subtitusi tepung daun kumis kucing P0 dan P1 memiliki cita rasa gurih. Rasa gurih tersebut berasal dari garam, meskipun garam yang digunakan relatif sedikit tetapi garam memiliki sifat pengatur rasa [15]. Sedangkan P2 dan P3 memiliki cita rasa yang sedikit pahit yang disebabkan karena penambahan tepung daun kumis kucing yang berlebihan akan menimbulkan aftertaste yang pahit, hal ini disebabkan karena tepung daun kumis kucingmengandung senyawa Saponin dalam bentuk glikosida yang ada pada tumbuhan yang umumnya menimbulkan rasa pahit [12].

\section{Kadar Kabohidrat Pada Sus Kering}

Kebutuhan karbohidrat makanan selingan untuk remaja berkisar antara 50-60\% dari total energi makanan selingan, sehingga didapatkan angka 26,25-31,5 g per satu takaran saji. Setelah dilakukan pengolahan, rata-rata hasil pengukuran kadar karbohidrat pada sus kering sebagai berikut, pada P0 rata-rata kadar karbohidrat 41,22 g/100 g yang memenuhi $10,30 \mathrm{~g}$ atau $32,69-39,23 \%$ dari total kadar karbohidrat makanan selingan per satu takaran saji, pada P1 39,71 g/100 g yang memenuhi 9,92 g atau 31,49- 37,79\% pada P2 37,78 g/100 g yang memenuhi $9,44 \mathrm{~g}$ atau $29,96-35,96 \%$ dan pada P3 rata-rata kadar karbohidrat 39,66 g/100 g yang memenuhi 9,91 $\mathrm{g}$ atau 31,46$37,75 \%$.Pengaruh proses pemaggangan terhadap karbohidrat suatu produk makanan umumnya 
berkaitan dengan hidrolisis yang dapat menyebabkan terjadinya gelatinisasi pati yang akan meningkatkan nilai cerna. Dan sebaliknya karbohidrat sederhana dan kompleks dalam reaksi millard dapat menurunkan ketersediaan karbohidrat dalam produk hasil pemanggangan. Sehingga hal tersebut dapat mempengaruhi nilai kadar karbohidrat dari suatu produk makanan [12] [16] [16] [17].

Pada Tabel 3 Hasil analisis kadar karbohidrat yang dilakukan dengan metode by difference sus kering substitusi tepung daun kumis kucing tergolong rendah yaitu, 9,92 g/25 g per satu takaran saji, jika dibandingkan dengan produk sejenis sus kering komersial dengan berbagai varian rasa yang memenuhi $14 \mathrm{~g} / 25$ g per satu takaran saji, dan juga jika dibandingakan dengan produk cookies subtitusi tepung daun kelor yang dapat memenuhi $12,27 \mathrm{~g} /$ 25 g per satu takaran saji [7] [18].

\section{Kadar Protein Pada Sus Kering}

Kebutuhan protein makanan selingan untuk remaja berkisar antara $15-20 \%$ dari total energi makanan ringan sehari, sehingga didapatkan angka 7,8 -10,5 $\mathrm{g}$ protein pada makanan selingan [16].Setelah dilakukan pengolahan, rata-rata hasil pengukuran kadar protein dalam sus kering subtitusi tepung daun kumis kucing pada P0 rata-rata kadar protein $13,38 \mathrm{~g} / 100 \mathrm{~g}$ yang dapat memenuhi $3,34 \mathrm{~g}$ atau $31,80-42,82 \%$ dari total kadar protein makanan selingan per satu takaran saji, pada P1 $14,87 \mathrm{~g} / 100 \mathrm{~g}$ yang dapat memenuhi 3,71 g atau 35,33-47,56\%. Pada P2 12,73 g/100g yang dapat memenuhi 3,18 g atau $30,28-40,76 \%$ dan pada P3 rata-rata kadar protein $13,46 \mathrm{~g} / 100 \mathrm{~g}$ yang dapat memenuhi $3,36 \mathrm{~g}$ atau $32-43 \%$ dari kadar protein makanan selingan per satu takaran saji. Rata-rata kadar protein dalam sus kering terjadi peningkatan dan penurunan dari perlakuan P0, P1, P2, dan P3.

Perbedaan kadar protein atau penurunan dan peningkatan protein pada suatu produk disebabkan oleh proses pengolahan dengan menggunakan suhu tinggi yang akan menyebabkan denaturasi protein sehingga terjadi koagulasi dan dapat menurunkan daya kemampuan larutnya. Selain itu, pemanasan protein dapat menyebabkan terjadinya reaksi-reaksi yang diharapkan maupun tidak, seperti reaksi denaturasi, kehilangan aktivitas enzim, perubahan kelarutan dan hidrasi, perubahan warna dan pemutusan ikatan peptida. Reaksi tersebut dapat disebabkan oleh lama pemanasan, $\mathrm{pH}$, antioksidan, radikal, dan senyawa aktif lain khususnya senyawa karbonil. Reaksi yang terjadi saat proses pemanasan dengan menggunakan suhu yang tinggi dapat merusak kondisi protein, sehingga dapat menurunkan kadar protein [12] [17] [19] [20].

Pada Tabel 4 Hasil analisis kadar protein sus kering substitusi tepung daun kumis kucing tergolong tinggi yaitu, 3,71 g/25 g per satu takaran saji, jika dibandingkan dengan produk sejenis sus kering komersial dengan berbagai varian rasa yang memenuhi $2 \mathrm{~g} / 25 \mathrm{~g}$ per satu takaran saji, dan juga jika dibandingakan dengan produk cookies subtitusi tepung daun kelor yang dapat memenuhi $2,98 \mathrm{~g} / 25$ g per satu takaran saji [7] [18].

\section{Kadar Lemak Pada Sus Kering}

Kebutuhan lemak makanan selingan berkisar antara 20-25\% dari total energi makanan selingan, sehingga didapatkan angka 4,66-5,83 g per satu takaran saji. Setelah dilakukan pengolahan, ratarata hasil pengukuran kadar lemak pada sus kering sebagai berikut, pada P0 rata-rata kadar lemak $37,59 \mathrm{~g} / 100 \mathrm{~g}$ yang memenuhi 9,39 gram atau 161,06 - 201,50\% dari total kadar lemak makanan selingan per satu takaran saji, pada P1 40,72 g/100 $\mathrm{g}$ yang memenuhi $10,18 \mathrm{~g}$ atau $174,61-218,45 \%$, pada P2 37,71 g/100g yang memenuhi 9,42 $\mathrm{g}$ atau $161,57-202,14 \%$, dan pada P3 39,95 g/100g yang memenuhi $9,98 \mathrm{~g}$ atau $171,18-214,16 \%$. Kadar lemak dalam sus kering terjadi peningkatan dan penurunan pada tiap perlakuan akan tetapi nilai kadar lemak tertinggi ada pada P1.

Perbedaan nilai kadar lemak dapat di pengaruhi oleh proses pengolahan bahan makanan. Tingkat kerusakannya sangat bervariasi tergantung suhu yang digunakan serta lamanya waktu proses pengolahan. Makin tinggi suhu yang digunakan, maka kerusakan lemak akan semakin intens. Terjadinya peningkatan dan penurunan kadar lemak dalam suatu produk disebabkan karena sifat lemak tidak tahan terhadap proses pemanasan dengan suhu tinggi.Tingkat kerusakannya kadar lemak sangat bervariasi tergantung suhu yang digunakan dan lama waktu proses pengolahan. Makin tinggi suhu yang digunakan, maka kerusakan lemak akan semakin besar. Selama proses pemasakan lemak akan mencair bahkan akan menguap (volatile) menjadi komponen lainnya seperti rasa (flavor) sehingga menyebabkan penurunan kadar lemak, sedangkan kenaikan kadar lemak disebabkan karena adanya penyerapan minyak oleh bahan makanan yang menyebabkan peningkatan kadar lemak dalam suatu produk. [16][17] [21]. 
Pada Tabel 3 Hasil analisis kadar lemak sus kering substitusi tepung daun kumis kucing tergolong tinggi yaitu, $10,18 \mathrm{~g} / 25 \mathrm{~g}$ per satu takaran saji, jika dibandingkan dengan produk sejenis sus kering komersial dengan berbagai varian rasa yang memenuhi $8 \mathrm{~g} / 25 \mathrm{~g}$ per satu takaran saji, dan juga jika dibandingakan dengan produk cookies subtitusi tepung daun kelor yang dapat memenuhi 4,13 g/ 25 g per satu takaran saji [7] [18].

\section{Energi Total Pada Sus Kering}

Kebutuhan energi dalam makanan selingan untuk remaja dikatakan kurang jika makanan selingan $<10 \%$ dari total kebutuhan, dikatakan baik jika memenuhi $10-20 \%$ total kebutuhan atau antara 210260 kkal dari total kebutuhan sehari, dan dikatakan lebih jika asupan energi makanan selingan $>20 \%$ dari total kebutuhan [22]. Untuk memunuhi kebutuhan energi makanan selingan maka untuk 1 takaran saji perkonsumi diberikan 25 gram sus kering sehingga energi yang didapatkan pada P0 yaitu $139,18 \mathrm{kkal} / 25 \mathrm{~g}$ sus kering yang dapat memenuhi 53,5 - 66,2\% dari total kebutuhan energi makanan selingan. Pada P1 146,21 kkal/ $25 \mathrm{~g}$ sus kering sehingga dapat memenuhi 56,2 - 69,6\%. Pada P2 135,36 kkal/ 25g sus kering yang dpat memenuhi 52,0 - 64,3\%. Dan pada P3 142,27 kkal/ $25 \mathrm{~g}$ sus kering yang dapat memenuhi $54,7-67,7 \%$ Kadar energi dalam sus kering relatif sama antar perlakuan P0, P1, P2, P3, akan tetapi untuk nilai kalori tertinggi dari semua perlakuan adalah $\mathrm{P} 1$. Nilai kalori semua perlakuan relatif sama disebabkan karena perhitungan energi menggunakan nilai kalori untuk protein dan karbohidrat 4 kkal dan lemak 9 kkal. Lemak menyumbangkan nilai kalori paling tinggi sehingga dimungkinkan dari ke empat perlakuan lemak dapat mengimbangi kadar energi dengan perbedaan komposisi tepung terigu dan tepung daun kumis kucing sebagai variabel bebas penelitian.

Pada Tabel 3 Hasil analisis Energi total sus kering substitusi tepung daun kumis kucing tergolong tinggi yaitu, 146,21 kkal /25 g per satu takaran saji, jika dibandingkan dengan produk sejenis sus kering komersial dengan berbagai varian rasa yang memenuhi $140 \mathrm{kkal} / 25 \mathrm{~g}$ per satu takaran saji, dan juga jika dibandingakan dengan produk cookies subtitusi tepung daun kelor yang dapat memenuhi 98,21 kkal /25 g per satu takaran saji [7] [18].

\section{KESIMPULAN}

Berdasarkan hasil penelitian dapat disimpulkan bahwa substitusi tepung daun kumis kucing tidak mempengaruhi kandungan zat gizi makro dan energi total pada sus kering. Pada Formulasi sus kering tepung daun kumis kucing dengan substitusi $10 \%$ merupakan komposisi yang paling dapat diterima dan dianjurkan untuk dikonsumsi dengan kandungan karbohidrat 9,92 g, protein 3,71 g, lemak 10,18 g, dan energi 146,71 kkal setiap $25 \mathrm{~g}$ sus kering. Anjuran konsumsi sus kering dengan substitusi $10 \%$ tepung daun kumis kucing sebanyak $\pm 50 \mathrm{~g}$ atau 2 takaran saji yang dapat memenuhi 1020 kebutuhan energi 2100-2600 kkal dalam sehari.

Penelitian selanjutnya dapat memodifikasi resep untuk mengganti penggunaan margarin dan juga agar dapat lebih memperhatikan suhu pemanasan dan pengeringan yang digunakan saat proses pembuatan sus kering dengan substitusi tepung daun kumis kucing.

\section{REFERENSI}

[1] V. R. Bowden and C. Smith Greenberg, Children and Their Families: The Continum of Care. Philadelphia: Saunders Company, 2010.

[2] World Health Organization, Latest global cancer data: Cancer burden rises to 18.1 million new cases and 9.6 million cancer death in 2018. Switzerland: World Health Organization, 2018.

[3] Kemenkes RI, Hasil Utama Riskesdas 2018. Jakarta: Kementrian Kesehatan Republik Indonesia, 2018.

[4] N. Sutandoyo, "Nutrisi pada Pasien Kanker Yang Men dapat Kemoterapi," Indonesian Joural of Cancer, vol. 1, no. 4, 2007.

[5] R. Hardiano, N. Huda, and Jumaini, "Gambaran Indeks Massa Tubuh Pada Pasien Kanker Yang Menjalani Kemoterapi," JOM, vol. 2, no. 2, 2015.

[6] Persatuan Ahli Gizi Indonesia, Penuntun Diet dan Terapi Gizi. Jakarta: EGC, 2019

[7] D. P. Dewi, "Substitusi tepung daun kelor (Moringa oleifera L.) pada cookies terhadap sifat fisik, sifat organoleptik, kadar proksimat, dan kadar Fe," Ilmu Gizi Indonesia , vol. 1, no. 2, 2018. 
[8] M. Almatar, H. Ekal, and Z. Rahmat, "A Glance on Medical Applications of Orthosiphon stamineus and Some of its Oxidative Compounds," International Journal of Pharmaceutical Sciences Review and Research, vol. 24, no. 2, 2014.

[9] S. Dwiny, "Aktifitas Antiangiogenesis Ekstrak Metanol Daun Kumis Kucing (Orthosiphon stamineus L) Terhadap Chorioallantoic Membrane Yang Diinduksi bFGF.," Universitas Sanata Darma, Yogyakarta, Skripsi 2014.

[10] I. Kusumaningrum, "Mempelajari Toksisitas Minuman Seduhan bubuk Daun Kumis Kucing (Orthosiphon stamineus benth) Terhadap Tikus Percobaan Secara In Vivo.," Fakultas Teknologi Pertanian IPB, Bogor, Laporan Penelitian 2005.

[11] N. Andarwulan, F. Kusnandar, and D. Herawati, Analisis Pangan. Jakarta: PT Dian Rakyat, 2011.

[12] F. G. Winarno, Kimia Pangan dan Gizi. Jakarta: PT Gramedia Pustaka Utama, 2004.

[13] E. Safitri, "Uji Hedonik Sus Kering Subtitusi Tepung Daun Kumis Kucing (Orthosiphonis Folium)," Universitas Negeri Malang, Malang, Skripsi 2016.

[14] T. M. Hildayanti, "Pengaruh Substitusi Bekatul dan Jenis Shortering Terhadap Sifat Organoleptik Sus Kering," Jurnal Tata Boga, vol. 6, no. 1, 2017.

[15] Y. B. Suhardjito, Pastry dalam Perhotelan. Yogyakarta: Andi Offset, 2006.
[16] N. S. Palupi; F. R. Zakaria; E. Prangdimurti, Pengaruh Pengolahan Terhadap Nilai Gizi Pangan. Bogor: Departemen Ilmu \& Teknologi Pangan, 2007.

[17] D. Sundari, Almasyhuri, and Astuti lamid, "Pengaruh Proses Pemasakan Terhadap Komposisi Zat Gizi Bahan Pangan Sumber Protein," Media Penelitian dan Pengembangan Kesehatan, vol. 25, no. 4, 2015.

[18] Nissin, Walens Choco Soes, Soes Kering Dengan Krim Coklat. Ungaran: PT Nissin Biscuit Indonesia, 2019.

[19] S. D. Saputri and S. Arum K, "Pengaruh Lama Pemasakan dan Temperatur Pemasakan Kedelai Terhadap Proses Ekstraksi Protein Kedelai Untuk Pembuatan Tahu," Universitas Diponegoro, Semarang, Skripsi 2009.

[20] Nurhidajah, S. Anwar, and Nurrahman, "Daya Terima dan Kualitas Protein In Vitro Tempe Kedelai Hitam (Glycine soja) Yang diolah pada suhu tinggi," Universitas Diponegoro, Semarang, Tesis 2009.

[21] R. Kesuma, S. D. Lestari, and I. Widiastuti, "Pengaruh Pemanasan Terhadap Kandungan Proksimat, Mineral dan Vitamin C Selada Air (Nasturtium Officinale)," Universitas Sriwijaya, Palembang, Skripsi 2019.

[22] K. Febriani, "Hubungan asupan energi jajanan Dengan prestasi Belajar Remaja Di SMP PL Domenico Savio Semarang," Falkultas Kedokteran Universitas Diponegoro, Semarang, Skripsi 2013. 